\title{
Determination of the Factors Affecting Future Expectations of Young People
}

\author{
Şefika Şule ERÇETİN ${ }^{1} \quad$ Halime GÜNGÖR² $\quad$ Mehmet HAMEDOĞLU3
}

\begin{abstract}
Future expectations of young people in a society are important factors that determine the development line and dynamics of that society. The aim of the study is to develop a measurement tool that determines the factors that $\mathrm{af}^{4}$ fect the future expectations of students in the school environment in the process of preparation for higher education. The validity and reliability studies of the scale were conducted with the 348 participants in the first and with 168 participants in the second application. As a result of exploratory and confirmatory factor analysis, the scale consisting of twenty five items and five factors was found to be theoretically and statistically appropriate. Since there are few tools that measure the factors that affect future expectations in the literature review, it is thought that the scale will contribute to the field in literature and can meet this need.
\end{abstract}

Keywords: Future expectations, factors related school, partial least square, structural equation modeling

\section{INTRODUCTION}

Education, which is one of the important indicators of the level of development of countries; it has important functions in shaping the individual, society, countries and the future world (Erçetin \& Arifoğlu, 2016). The process of preparation for higher education is of particular importance in the realization of the future expectations of the individuals who influence and contribute to the development level of the countries. Because, high school period, which is the process of transition to adulthood, is a process in which young people are prepared to make important decisions about their lives such as career choice, transition to higher education, business life, emotional relations and marriage. These decisions are very important as they will affect not only the work lives of young people, but also their standards of living and life preferences. The fact that young people of high school age have to make such important decisions makes it difficult for them to make right and rational decisions if they are not aware of professional development (Şimşek, 2012). At the end of the high school term when compulsory education ends, young people who are unable to determine their life goals and decide how they want their life to progress after high school will be concerned about their future. Future expectations of young people in a society are important factors that determine the development line and dynamics of that society. In industrialized societies where competition and success for economic life are at the forefront, future anxiety for young people starts from childhood (Şanlı \& Saraçlı, 2015). People who are unable to make their future design well and unable to fulfill their expectations are likely to experience intense feelings of despair and be left alone with stress (Tuncer, 2011a). Future expectations are one of the factors that affect the individual's experiences in later life. The fact that the positive experiences enable both the people to carry out their tasks successfully in the period they are in, and to increase their expectations and to perform at higher levels in their later life (Tuncer, 2011b).

Studies on the expectation of the future started in the first quarter of the 21st century and revived in the middle of the century (Şimşek, 2012; Şanlı \& Saraçl1, 2015). W. I. Thomas, one of the pioneers of the studies on the future expectation, underlined the importance and effect of the expectations with the phrase "the meaning of an action or behavior does not originate from the nature of that action or behavior. If a person accepts a situation as real,

\footnotetext{
${ }^{1}$ Hacettepe University, Ankara, Turkey, Orcid ID: https://orcid.org/0000-0002-7686-4863, sefikasule@gmail.com ${ }^{2}$ Hacettepe University, Ankara, Turkey, Orcid ID: https://orcid.org/0000-0002-3283-1250, gungor.halime@gmail.com

3Sakarya University, Sakarya, Turkey, Orcid ID: https://orcid.org/ 0000-0003-2833-2931, mhamed@sakarya.edu.tr
} 
the results are also true, and people impose certain meanings on the actions and these meanings affect their future behavior' in 1920 (Şanlı \& Saraçlı, 2015; Şimşek, 2012).

Seigner (2003) found that the conceptualization of future prospects was based on the early studies of Frank (1939), Israeli (1930) and Lewin (1939), according to this;

a) Future orientation or possible future actions and experiences occur in the future.

b) Future orientation involves the special and individual structure of individuals' future images in relation to different areas.

c) The content of these areas can be personal or social, realistic or ideal and truthful or fantastic.

Looking at the studies on future expectations, it can be said that the adaptation of the FESA Future Expectations Scale for Adolescents, developed by McWhirter and McWhirter (2008), was conducted by Tuncer (2011a) at a randomly selected school in Elazığ. In this context, the scale was applied to 175 secondary school students. The scale was adapted to Turkish. The original scale consists of 25 items and all items begin with "When I am an adult". The lowest score in the scale is 1 and the highest score is 7 . The items of the scale are scored as 1 : I absolutely do not believe "and" 7: I absolutely believe".

Positive Future Expectation Scale which consists of 5 items and has alpha reliability coefficient of .85, which aims to measure the positive degree of expectations of individuals about their personal future was used by İmamoğlu and Güler-Edwards (2007) in order to determine the patterns of future orientation of young people and to investigate how the related orientations differ according to the self-types predicted by the Balanced Integration and Discrimination (Balance) Model.

When the studies in the literature on future expectations are analyzed, it is observed that the studies on future expectations are limited. Various authors state that despite the importance of the subject, the scattered and limited researches are inadequate in measuring instruments and new scales are needed (İmamoğlu and GülerEdwards, 2007). Seijts (1998) refers to the problem of scale in the evaluation paper on the subject and states that studies comparing various scales in terms of validity should be done.

The aim of the study is to develop a measurement tool that determines the factors that affect the future expectations of students in the school environment in the process of preparation for higher education. In this study, the issue of future expectations has been addressed only in the context of the preparation process for higher education.

\section{METHOD}

\section{Preparation Process of Scale}

The Future Expectations Scale was planned to be prepared in the form of three different forms for the students, teachers and administrators. In this respect, the preparatory stages of The Future Expectations Scale are as follows.

1. In the preparation process, firstly, the literature was surveyed, the existing studies on the factors affecting the future expectations were examined, the factors related to the school which were thought to affect the future expectations were listed in line with the literature review and 15 items were prepared accordingly.

2. After the literature review was completed, the factors affecting future expectations related to school were categorized into 5 dimensions: school administrators and management style, parents, teachers, school qualifications and students.

3. The categories were structured according to the dimensions of the vision concept discussed with holistic approach by Erçetin (2000) in the Vision of the Leader Spiral. The issue of vision in leadership was studied by 
Erçetin at different school levels and the importance of 21st century leadership was emphasized. According to Erçetin $(1997 ;$ 2001a) vision is the dream and design of the future, the leading elementary school administrators with vision are people dreaming and designing the futures of their schools (Erçetin, 2001a). Furthermore, in the 21st.century, vision must be considered as a key concept when it is recognized that the new and changed roles of the universities must be moved from teacher-centered to learner-centered environments, and the roles of the university administrators must be moved from managers and technicians to leadership (Erçetin, 2001b). Scale items were redesigned accordingly in terms of Erçetin's vision concept with holistic approach. According to Erçetin (2000) the dimensions of the concept of vision as follow;

Vision is to dream and design the future: Imagination can be evaluated as an indicator of intellectual, emotional and intuitive wealth. Those who dream do not confine themselves with the existing; do not limit themselves and their lives with known. While fearless orientation to the unknown, uncertainty; they design what they should exist by adding their creativity. Visionary leaders are the ones who dream and design the future of their societies and organizations.

The vision is to balance and construct dreams with reality: Visionary leaders are the ones who can evaluate the existing conditions, opportunities and situation of themselves and their organizations with a simple reality. They use these assessments as a basis for reaching the future and new dreams that they have designed and created for their organizations. They also turn their dreams into realizable target dreams.

Vision is to differentiate with values, to integrate with the power of heart in values: In the concept of vision, creativity that dreams of the future by running all the intellectual, emotional and intuitive wealth; by trying to comprehend the meaning of the past in this day from existing known conditions; the perception and interpretation of a reality that creates and designs the future, transforms them into dreams and integrates the essence into values with new achievements. Because visionary leaders see the value of people's achievements and behaviors for life in their societies and organizations, and value them beyond valid judgment criteria and systems of appreciation; they are the ones who shape the future by re-evaluating all values, motivating people to new successes and new successes. Visionary leaders who differentiate their societies and organizations with the values they put forward within the scope of human accomplishments, everything that people find meaningful; They are the people who integrate people with their hearts in the excitement and confidence of the process of achieving new achievements which they see as a precondition of maintaining their existence and preparing the future.

Vision is to convey and share: The vision is to convey and share that they dream and design, balance and construct dreams and facts, differentiate them with their values, and are ready to integrate them with the power of heart. Many people have dreams, projects, fictions and unique values about their society and organization. However, when these are not communicated by explaining, not communicating by sharing; when it is not reintegrated by sharing, it remains only in itself, in dreams and thoughts. However, the concept of vision includes both imaginary-intellectual and operational dimensions. For this reason, visionary leaders explain and communicate their dreams, designs, fictions and values.

The vision is to take risk and manage risk: The vision is to dream and design the future, to balance and construct the reality with dreams, to differentiate with values and to integrate, communicate and share with the heartfelt in values. All these can be done by people who can take risks. Because each dimension given above expands both in and of itself requires to take risk and be brave, as well as to assume and manage the responsibilities that the risk will bring. For this reason, visionary leaders are those who can take risks and manage risks. Visionary leaders develop strategies and action options to turn their risk into success.

4. Separate forms of Future Expectations Scale were prepared for three groups as Student, Teacher and Administrator. Student, teacher and administrator forms were composed of items in parallel with the same content. 
5. Scale forms were finalized by taking the opinions of experts from the field of statistics and educational management. Then a personal information form was prepared before the application phase.

In the Student Form, the variables such as self-step status, right-death status, together-separation status of parents, gender, education status of the parents, and willingness to continue higher education were taken into consideration as personal information. In the Administrators Form, variables such as gender, educational background, managerial experience, working time in the school worked were taken into consideration. In the Teacher Form, variables such as gender, age, educational background, branch, seniority and duration of work at the school were taken into consideration.

As a result of the first application, the scale was revised and reapplied. In line with expert opinions, the scale was reduced to a single form and the personal information form included with duties in school (teacher / administrator / student) and gender variables. The structural design of the scale is shown in Table 1 
Table 1.

Structural Design of Future Expectations Scale

\begin{tabular}{|c|c|c|c|c|}
\hline Categories & Vision Dimensions & Student Form & Teacher Form & Administrators Form \\
\hline \multirow[t]{5}{*}{ Management } & $\begin{array}{l}\text { Dreaming and designing } \\
\text { the future }\end{array}$ & $\begin{array}{l}\text { The school administration organizes } \\
\text { studies to enrich my dreams about } \\
\text { the future in school }\end{array}$ & $\begin{array}{l}\text { Organizing studies at school to } \\
\text { enrich the dreams of my students } \\
\text { about the future }\end{array}$ & $\begin{array}{l}\text { Organizing studies in the school to } \\
\text { enrich the students' dreams about the } \\
\text { future }\end{array}$ \\
\hline & $\begin{array}{l}\text { Balancing reality with } \\
\text { dreams }\end{array}$ & $\begin{array}{l}\text { The school administration organizes } \\
\text { extracurricular activities to help me } \\
\text { recognize my interests and abilities }\end{array}$ & $\begin{array}{l}\text { Organizing extracurricular activities } \\
\text { at the school to help my students } \\
\text { recognize their interests and abilities }\end{array}$ & $\begin{array}{l}\text { Organizing extracurricular activities } \\
\text { at the school to help students } \\
\text { recognize their interests and abilities }\end{array}$ \\
\hline & Integration with values & $\begin{array}{l}\text { Regardless of what happens in the } \\
\text { future, the school administration } \\
\text { organizes social responsibility } \\
\text { projects to improve our sensitivity to } \\
\text { social problems. }\end{array}$ & $\begin{array}{l}\text { Organizing social responsibility } \\
\text { projects in order to improve my } \\
\text { students' sensitivity to social } \\
\text { problems }\end{array}$ & $\begin{array}{l}\text { Organizing social responsibility } \\
\text { projects to improve students' } \\
\text { sensitivity to social problems }\end{array}$ \\
\hline & Conveying and sharing & $\begin{array}{l}\text { The school management offers } \\
\text { sharing environments where we can } \\
\text { talk to friends about what we want to } \\
\text { do in the future }\end{array}$ & $\begin{array}{l}\text { Presenting sharing environments in } \\
\text { the school where my students can } \\
\text { talk to friends about what they want } \\
\text { to do in the future }\end{array}$ & $\begin{array}{l}\text { Providing sharing environments } \\
\text { where students can talk to their } \\
\text { friends about what they want to do } \\
\text { in the future }\end{array}$ \\
\hline & Taking and Managing & The school management organizes & Organizing guidance seminars on & Organizing guidance seminars on \\
\hline
\end{tabular}




\begin{tabular}{|c|c|c|c|c|}
\hline & Risks & $\begin{array}{l}\text { guidance seminars on how to cope } \\
\text { with the obstacles that we will face in } \\
\text { realizing our dreams }\end{array}$ & $\begin{array}{l}\text { how to cope with the obstacles my } \\
\text { students will face in realizing their } \\
\text { dreams }\end{array}$ & $\begin{array}{l}\text { how to cope with the obstacles that } \\
\text { students will face in realizing their } \\
\text { dreams }\end{array}$ \\
\hline \multirow[t]{5}{*}{ Parents } & $\begin{array}{l}\text { Dreaming and designing } \\
\text { the future }\end{array}$ & $\begin{array}{l}\text { My parents support me about my } \\
\text { dreams for the future }\end{array}$ & $\begin{array}{l}\text { Parents' support of their child's } \\
\text { dreams about the future }\end{array}$ & $\begin{array}{l}\text { Parents' support of their child's } \\
\text { dreams about the future }\end{array}$ \\
\hline & $\begin{array}{l}\text { Balancing reality with } \\
\text { dreams }\end{array}$ & $\begin{array}{l}\text { My parents support me in setting } \\
\text { goals that I can achieve rather than } \\
\text { my own wishes when planning my } \\
\text { future }\end{array}$ & $\begin{array}{l}\text { Parents support their child to set } \\
\text { goals that s/he can achieve rather } \\
\text { than his/her own wishes when } \\
\text { planning the future }\end{array}$ & $\begin{array}{l}\text { Parents support their child to set } \\
\text { goals that s/he can achieve rather } \\
\text { than his/her own wishes when } \\
\text { planning the future }\end{array}$ \\
\hline & Integration with values & $\begin{array}{l}\text { My parents enlighten me on } \\
\text { choosing the profession that I will be } \\
\text { happy with }\end{array}$ & $\begin{array}{l}\text { Enlighten the parents to choose the } \\
\text { profession that will make their child } \\
\text { happy }\end{array}$ & $\begin{array}{l}\text { Enlighten the parents to choose the } \\
\text { profession that will make their child } \\
\text { happy }\end{array}$ \\
\hline & Conveying and sharing & $\begin{array}{l}\text { I can talk to my parents about what } \\
\text { kind of life that I want to have in the } \\
\text { future }\end{array}$ & $\begin{array}{l}\text { Parents can chat with their child } \\
\text { about what kind of life the child } \\
\text { wants to have in the future }\end{array}$ & $\begin{array}{l}\text { Parents can chat with their child } \\
\text { about what kind of life the child } \\
\text { wants to have in the future }\end{array}$ \\
\hline & $\begin{array}{l}\text { Taking and Managing } \\
\text { Risks }\end{array}$ & $\begin{array}{l}\text { My parents encourage me to cope } \\
\text { with the challenges that I will face in } \\
\text { fulfilling my expectations }\end{array}$ & $\begin{array}{l}\text { Parents encourage their child to cope } \\
\text { with the challenges they will face in } \\
\text { fulfilling their expectations }\end{array}$ & $\begin{array}{l}\text { Parents encourage their child to cope } \\
\text { with the challenges they will face in } \\
\text { fulfilling their expectations }\end{array}$ \\
\hline Teachers & $\begin{array}{l}\text { Dreaming and designing } \\
\text { the future }\end{array}$ & $\begin{array}{l}\text { My teacher chatting with me about } \\
\text { the profession that I want to be in the }\end{array}$ & $\begin{array}{l}\text { My students can chat with me about } \\
\text { the profession that they want to be in }\end{array}$ & $\begin{array}{l}\text { Teachers can chat with students } \\
\text { about the profession that they want }\end{array}$ \\
\hline
\end{tabular}



future
the future
to be in the future

\begin{tabular}{llll}
\hline $\begin{array}{l}\text { Balancing reality with } \\
\text { dreams }\end{array}$ & $\begin{array}{l}\text { My teacher helps me find out what } \\
\text { my interests are }\end{array}$ & $\begin{array}{l}\text { Helping my students find out what } \\
\text { their interests are }\end{array}$ & $\begin{array}{l}\text { Teachers help students find out what } \\
\text { their interests are }\end{array}$
\end{tabular}

\begin{tabular}{llll}
\hline Integration with values & $\begin{array}{l}\text { My teacher talks to us that if we are } \\
\text { hardworking students we can come } \\
\text { one step closer to our dreams }\end{array}$ & $\begin{array}{l}\text { I can talk to my students that they } \\
\text { can be one step closer to their dreams } \\
\text { if they are hardworking }\end{array}$ & $\begin{array}{l}\text { Teachers talk about that they can get } \\
\text { one step closer to their dreams if they } \\
\text { become hardworking with students }\end{array}$ \\
\hline Conveying and sharing & $\begin{array}{l}\text { I can talk to my teacher about what } \\
\text { kind of work I want to have in the } \\
\text { future }\end{array}$ & $\begin{array}{l}\text { To be able to talk to my students } \\
\text { about what kind of work life they } \\
\text { want in the future }\end{array}$ & $\begin{array}{l}\text { Teachers can talk to students about } \\
\text { what kind of work life they want in } \\
\text { the future }\end{array}$ \\
\hline $\begin{array}{l}\text { Taking and Managing } \\
\text { Risks }\end{array}$ & $\begin{array}{l}\text { My teacher enlightens me on what } \\
\text { stages that I will go through while } \\
\text { realizing my dreams }\end{array}$ & $\begin{array}{l}\text { To enlighten my students about what } \\
\text { stages that they will go through } \\
\text { while realizing their dreams }\end{array}$ & $\begin{array}{l}\text { Teachers enlighten the students } \\
\text { about the stages that they will go } \\
\text { through while realizing their dreams }\end{array}$
\end{tabular}

\begin{tabular}{llll}
\hline $\begin{array}{l}\text { School } \\
\text { Qualifications }\end{array}$ & $\begin{array}{l}\text { Dreaming and designing } \\
\text { the future }\end{array}$ & $\begin{array}{l}\text { School guidance activities were held } \\
\text { to make me think about where I saw } \\
\text { myself after five years. }\end{array}$ & $\begin{array}{l}\text { School guidance activities will be School guidance activities will be } \\
\text { where they see themselves after five } \\
\text { where they see themselves after five } \\
\text { years. }\end{array}$
\end{tabular}
Balancing reality with
dreams
Conducting classroom guidance
activities where we can recognize our
Conducting classroom guidance
activities in the school where my
students can recognize their

Conducting classroom guidance activities where students can recognize their strengths and 


$\begin{array}{llll}\text { Integration with values } & \begin{array}{l}\text { We have a school environment that } \\ \text { teaches us to respect differences }\end{array} & \begin{array}{l}\text { We have a school environment that } \\ \text { teaches students to respect }\end{array} & \begin{array}{l}\text { We have a school environment that } \\ \text { tifferences }\end{array} \\ & \text { teaches students to respect } \\ \text { differences }\end{array}$

\begin{tabular}{llll}
\hline Conveying and sharing & $\begin{array}{l}\text { Organizing vocational guidance } \\
\text { activities in the school where we can } \\
\text { discuss our future expectations }\end{array}$ & $\begin{array}{l}\text { Organizing vocational guidance } \\
\text { activities in the school where } \\
\text { students can discuss their future } \\
\text { expectations }\end{array}$ & $\begin{array}{l}\text { Organizing vocational guidance } \\
\text { activities in the school where } \\
\text { students can discuss their future } \\
\text { expectations }\end{array}$
\end{tabular}

\begin{tabular}{llll}
\hline Taking and Managing & Conduct classroom guidance & Conducting classroom guidance & Conduct classroom guidance \\
Risks & activities to improve our skills in & activities in which my students will & activities to improve students' ability \\
& coping with challenges at school & $\begin{array}{l}\text { develop their skills in coping with } \\
\text { difficulties at school }\end{array}$ & to cope with challenges at school
\end{tabular}

\begin{tabular}{llll}
\hline Students & $\begin{array}{l}\text { Dreaming and designing } \\
\text { the future }\end{array}$ & $\begin{array}{l}\text { I have dreams about what kind of life } \\
\text { that I want to have in the future }\end{array}$ & $\begin{array}{l}\text { Students have dreams about what } \\
\text { kind of life that they want to have in } \\
\text { the future }\end{array}$
\end{tabular}

\begin{tabular}{llll}
\hline Balancing reality with & Knowing in which direction that I \\
dreams & $\begin{array}{l}\text { need to develop my skills to realize } \\
\text { my dreams }\end{array}$ & $\begin{array}{l}\text { so know in which direction students } \\
\text { should develop their talents in order } \\
\text { to realize their dreams }\end{array}$ & $\begin{array}{l}\text { To know in which direction students } \\
\text { should develop their talents in order } \\
\text { to realize their dreams }\end{array}$
\end{tabular}

\begin{tabular}{llll}
\hline Integration with values & $\begin{array}{l}\text { Whatever I am in the future, } \\
\text { knowing that I have to be an honest }\end{array}$ & $\begin{array}{l}\text { The student knows that no matter } \\
\text { what work he or she does in the }\end{array}$ & $\begin{array}{l}\text { The student knows that no matter } \\
\text { what work he or she does in the }\end{array}$
\end{tabular}




\begin{tabular}{|c|c|c|c|}
\hline & person & $\begin{array}{l}\text { future, s/he should be an honest } \\
\text { person }\end{array}$ & $\begin{array}{l}\text { future, s/he should be an honest } \\
\text { person }\end{array}$ \\
\hline Conveying and sharing & $\begin{array}{l}\text { To share with my friends about the } \\
\text { profession that I want to do in the } \\
\text { future }\end{array}$ & $\begin{array}{l}\text { Sharing with friends about the } \\
\text { profession that students want to do } \\
\text { in the future }\end{array}$ & $\begin{array}{l}\text { Sharing with friends about the } \\
\text { profession that students want to do } \\
\text { in the future }\end{array}$ \\
\hline $\begin{array}{l}\text { Taking and Managing } \\
\text { Risks }\end{array}$ & $\begin{array}{l}\text { I have courage to overcome the } \\
\text { obstacles that I will face while } \\
\text { realizing my dreams }\end{array}$ & $\begin{array}{l}\text { Students have the courage to } \\
\text { overcome the obstacles that they will } \\
\text { face while realizing their dreams }\end{array}$ & $\begin{array}{l}\text { Students have the courage to } \\
\text { overcome the obstacles that they will } \\
\text { face while realizing their dreams }\end{array}$ \\
\hline
\end{tabular}




\section{Sample}

The universe of study is 211 official high school education institutions in Bursa. Based on the E-School Management Information System, the base points of the 2014-2015 academic year were taken from the junior high school students of the 12th grade in the 2018-2019 academic year and the scores were ranked from small to large. In order to ensure internal consistency in the scale, both the most successful and the most unsuccessful schools were selected as samples. Öztimurlar Vocational and Technical Anatolian High School and Bursa Erkek High School which are among the lowest and highest schools were taken as the sample. The application was made by the researchers after obtaining the necessary permissions. The sample consisted of voluntary participation.

Table 2.

Characteristics of School Sample of the First and Second Application

\begin{tabular}{|c|c|c|c|c|c|c|c|c|c|}
\hline \multirow[t]{2}{*}{ Application School } & \multicolumn{3}{|c|}{ Student } & \multicolumn{3}{|c|}{ Administrator } & \multicolumn{3}{|c|}{ Teacher } \\
\hline & $N$ & $n_{1}$ & $n_{2}$ & $N$ & $n_{1}$ & $n_{2}$ & $N$ & $n_{1}$ & $n_{2}$ \\
\hline Öztimurlar VTAHL & 662 & 130 & 51 & 5 & 4 & 3 & 72 & 60 & 8 \\
\hline Erkek High School & 769 & 98 & 67 & 5 & 4 & 3 & 64 & 52 & 36 \\
\hline Total & 1431 & 228 & 118 & 10 & 8 & 6 & 136 & 112 & 44 \\
\hline
\end{tabular}

According to Table 2, research population consists of 1431 students, 10 administrators and 136 teachers and 1577 people. $38.22 \%(\mathrm{n} 1=133)$ of the participants were female, $65.52 \%(\mathrm{n} 1=228)$ were students, $2.3 \%(\mathrm{n} 1=8)$ were administrators, $32.18 \%(\mathrm{n} 1=112)$ were teachers, $55.75 \%(\mathrm{n} 1=194)$ were from Öztimurlar Vocational Technical High School and 44.15\% (n1 = 154) from Erkek High School. 59.5\% (n2 $=100)$ were male, $70.2 \%(\mathrm{n} 2=118)$ were students, $3.6 \%(\mathrm{n} 2=6)$ were administrators, $26.2 \%(\mathrm{n} 2=44)$ were teachers, $36.9 \%(\mathrm{n} 2=62)$ were from Öztimurlar Vocational Technical Anatolian High School and $63.1 \%(n=106)$ were from Erkek High School. Finally, in the first application 348, in the second application 168 people participated in the study.

\section{The Future Expectations Scale}

The Future Expectations Scale consists of five dimensions as school administrators and management style, contribution of parents, teacher-related factors, school characteristics, the impact of students' individual characteristics. Each dimension is composed of 25 items, one item per each of the 5 vision dimensions discussed by Erçetin (2000). In the scale, 5- Likert-Type rating was used as 5-It definitely affects the future expectations of students, 4- It affects students' future expectations, 3-It partially affects the future expectations of students, 2- It does not affect students' future expectations, 1-It does not exactly affect the future expectations of the students. 


\section{Statistical Analysis}

After the application, the data were processed and SPSS 23.0 Statistical Program was used for the analysis of the first application and Smart PLS 3 program was used for the analysis of the second application. When the analyzes of the student, administrator and teacher forms were made separately, since the sample number of the administrators and teachers was not sufficient for the analysis and the scale items in the forms were prepared in the same parallel as the content, the data of the student, teacher and administrator groups were combined into a single form and the application was repeated.

In the term of to preference of the PLS-SEM is allowed for much flexibility in terms of data requirements and the specification of relationships between constructs and indicator variables (Sarstedt et al, 2017). In this paper, we examined the distributional assumption with the Shapiro-Wilks test and the data weren't $\mathrm{t}$ fit the distributional assumption. Our sample size was small compared to the population of the Bursa. In the literature, the factor-based SEM offers robust parameter estimation for the small sample sizes.

\section{FINDINGS}

Before factor analysis, Kaiser Meyer Olkin (KMO) coefficient was calculated and Bartlett's Sphericity test was applied to determine the suitability of the data for factor analysis. KMO coefficient was calculated as .924 and Bartlett's Sphericity value $(\chi 2=6187.055, p<.01)$ was determined. Accordingly, there is no relationship between the items, so factor analysis can be performed.

Exploratory Factor Analysis was performed with "varimax" method. As a result of the analyzes, 5 dimensions were not formed as planned in the preparation stage of the Future Expectations Scale, 4 dimensions were formed and factor loadings were meaningful, there were no items to be disposed, 5th item in the school administrators and management style dimension shifted to teacher-related factors dimension, it was found that teacher-related factors dimension and school characteristics dimension seem to be the only factor. In this sense, the 5th item in the form of school administrators and the management style and the items related to the teacher-related factors and school characteristics that appeared as one dimension were revised in line with the expert opinions.

In accordance with the opinions of the experts, the scale prepared as 3 separate forms for teachers, students and administrators was reduced to a single form and the scale was finalized and the application was repeated. The results of the repeated application are as follows.

The validity and reliability studies of the scale were performed by using Smart PLS 3 program, factor analysis and path analysis were performed. According to factor analysis, in the first model, since all of the factor loadings were above 0.7 , the distribution of the previously determined items to the factors developed as we expected. As a result of the analysis, it was seen that the items were collected under five factors and all factors have five items that scale include totally 25 items. Factor's loads ranging are respectively; Contribution of Parents Factor from .852 and .770; School Administrators and Management Style from .883 and .820 ; School Characteristics from .865 and .795; Teacher-Related Factors from .853 and .779; the Impact of Students' Individual Characteristics from .832 and .730. 


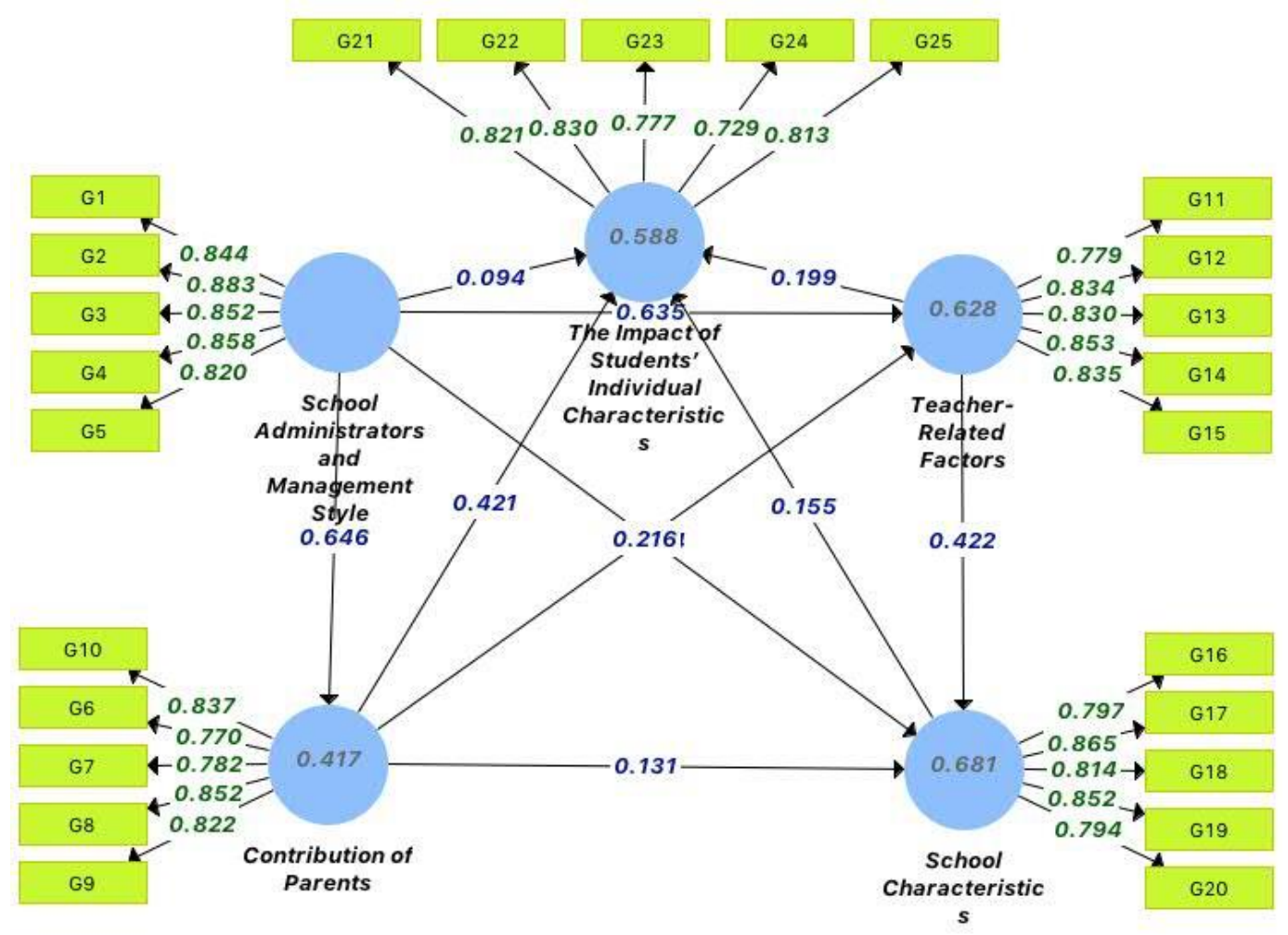

Figure 1. Path Model-1 of the Factors Affecting Future Expectations

Cronbach's alpha coefficients for Contribution of Parents Factor was calculated as .872, Cronbach's alpha coefficient for School Administrators and Management Style Factor was calculated as .905, Cronbach's alpha coefficient for School Characteristics Factor was calculated as .882, Cronbach's alpha coefficient for Teacher-Related Factors Factor was calculated as .884, Cronbach's alpha coefficient for the Impact of Students' Individual Characteristics Factor was calculated as .854.

Table 3.

Construct Reliability and Validity of the Model 1

\begin{tabular}{llcll}
\hline Factors & $\begin{array}{l}\text { Cronbach's } \\
\text { Alpha }\end{array}$ & rho_A & $\begin{array}{l}\text { Composite } \\
\text { Reliability }\end{array}$ & $\begin{array}{l}\text { Average } \\
\text { Variance } \\
\text { Extracted } \\
\text { (AVE) }\end{array}$ \\
& & & & \\
Contribution of Parents & .872 & .875 & .907 & .661 \\
School Administrators and Management Style & .905 & .906 & .930 & .725 \\
School Characteristics & & & & .680 \\
\end{tabular}


Teacher-Related Factors

The Impact of Students' Individual Characteristics
.884

.854
.886

.915

.857

.895
.683

.632

Secondly, it is seen that the composite reliability values of the model vary between .895 and .930 . For reliability, the composite reliability values of any measurement model should be .80 and above. Therefore, it is seen that all composite reliability values are quite high. Rho_A is seen to vary between .906 and .857 . When the AVE values of the model are examined, it is seen that these values vary between .632 and .725 values. Therefore, it can be said that AVE values of the measurement model meet the condition of being .50 and above. Fornell and Larcker (1981) recommend that CR (composite reliability) should be above 0.8 and AVE value should be above 0.5 for good compliance validity. We see that the construct validity and reliability values of the scale are higher than expected.

In order to check the discriminant validity of the model, Fornell-Larcker values and the correlation values of the factors were examined. Fornell-Larcker values were found to vary between .852 and .795. Correlation values vary between .624 and .778. For validity, Fornell-Larcker values obtained by Wong (2013) should be higher than the correlation values in rows and columns of latent variables. In all cases, since the crosstab values are higher than the values in the row and column, it can be said that the discriminant validity of the scale is supported.

$\mathrm{Hu}$ and Bentler (1998) defined SRMR as difference between the model implied correlation matrix and the observed correlation; so values less than 0.08 are considered appropriate. SRMR produces a value of 0.056 in model. So we can say that the model produces good fit. The NFI results in values between 0 and 1 and the closer the NFI to 1 , the better the fit (Ringle et al., 2015). NFI produces a value of .809 in model. The chi-square value ( $c 2=599.366 ; \mathrm{p}<0.001)$ appears to be significant. d_ULS value of the model is 1.020 , d_G value of the model is .66.

RMS Theta values below 0.12 indicate a well-fitting model, whereas higher values indicate a lack of fit (Henseler, et al., 2014). Although RMS Theta is 0.145 for this model, since the SRMR, NFI was better than the expected values, and the Chi-square value was significant, the model was considered to be in good fit.

Factor bookstraping were made to test the model structure. Contribution of Parents was explained by $13 \%(R 2=0.131)$ of School Characteristics, $21 \%(R 2=0.216)$ of the Teacher-Related Factors, and $42 \%(R 2$ $=0.421)$ of the Impact of Students' Individual Characteristics. School Administrators and Management Style was explained by \%64 $(R 2=0.646)$ of Contribution of Parents, \% $22(R 2=0.216)$ of School Characteristics, \% $63.5(R 2=0.635)$ of Teacher-Related Factors and \%1 $(R 2=0.094)$ of the Impact of Students' Individual Characteristics. School Characteristics was explained by $\% 15.5(R 2=0.155)$ of the Impact of Students' Individual Characteristics. Teacher-Related Factors was explained by \%42 (R2 = 0.422) of School Characteristics and by \% $19(R 2=0.199)$ of the Impact of Students' Individual Characteristics.

According to the results obtained from the T-statistic in the model, paths between Contribution of Parents $>$ School Characteristics $(t=2.142 ; p<0.05)$, Contribution of Parents $>$ The Impact of Students' 
Individual Characteristics $(t=4.714 ; p<0.05)$, School Administrators and Management Style > Contribution of Parents $(t=9.640 ; p<0.05)$, School Administrators and Management Style $>$ School Characteristics $(t=3.911 ; p<0.05)$, School Administrators and Management Style $>$ Teacher-Related Factors $(t=7.323 ; p<0.05)$, Teacher-Related Factors $>$ School Characteristics $(t=4.500 ; p<0.05)$, TeacherRelated Factors $>$ The Impact of Students' Individual Characteristics $(t=2.265 ; p<0.05)$ are statistically significant.

Paths between Contribution of Parents $>$ Teacher-Related Factors $(t=2.583 ; p>0.05)$, School Administrators and Management Style $>$ The Impact of Students' Individual Characteristics $(\mathrm{t}=0.825 ; \mathrm{p}>$ 0.05), School Characteristics $>$ The Impact of Students' Individual Characteristics $(t=1.913 ; p>0.05)$ are not statistically significant. Similar results were obtained when path analysis and path bookstraping were performed.

According to the results of the first model paths between School Administrators and Management Style $>$ The Impact of Students' Individual Characteristics and School Characteristics > The Impact of Students' Individual Characteristics were removed from the model because they are not statistically significant. Although path between Contribution of Parents > Teacher-Related Factors is not statistically significant, because there are difficulties in the decrease of disclosure rates of Teacher-related factors, at the end of trials, the direction of the path between Contribution of Parents $>$ Teacher-Related Factors was changed and the model was reconstructed. Factor analysis results of the second model are given in Table 4.

\section{Table 4.}

Factor Analysis Results of the Model 2

\begin{tabular}{|c|c|c|c|c|c|c|}
\hline Factors & Items & $\begin{array}{l}\text { Item } \\
\text { Loadings }\end{array}$ & $\begin{array}{l}\text { Cronbach's } \\
\text { Alpha }\end{array}$ & rho_A & $\begin{array}{l}\text { Composite } \\
\text { Reliability }\end{array}$ & $\begin{array}{l}\text { Average } \\
\text { Variance } \\
\text { Extracted } \\
(\mathrm{AVE})\end{array}$ \\
\hline
\end{tabular}

Contribution of Parents $\quad$ G10 $\quad .837$

G6 $\quad .770$

$\begin{array}{llllll}\text { G7 } & .782 & .872 & .875 & .907 & .661\end{array}$

G8 $\quad .852$

G9 $\quad .822$

School Administrators $\quad$ G1 $\quad .845$

and Management Style

(1)

.905

$.906 \quad .930$

.725

G2 $\quad .884$ 


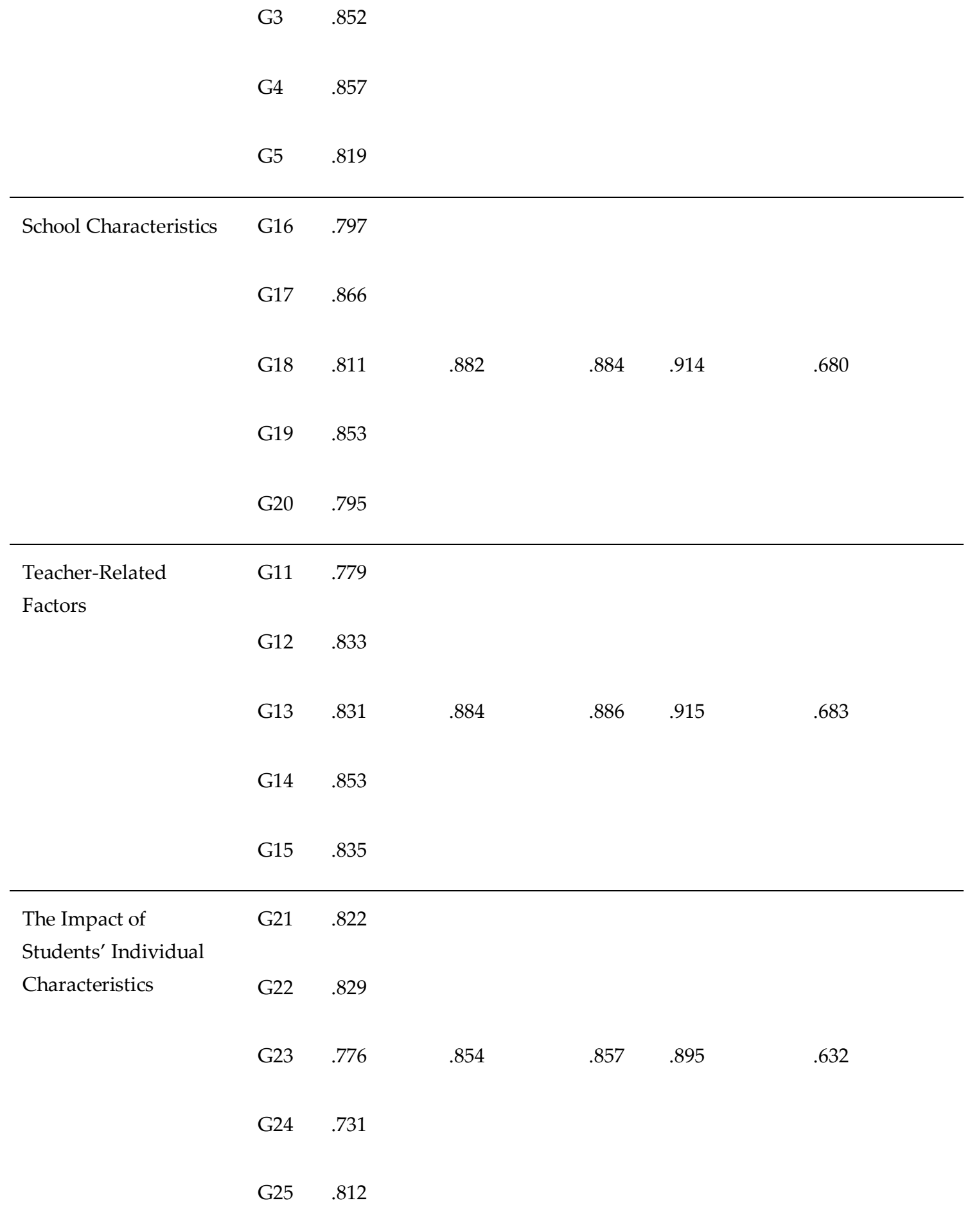

As a result of the analysis, it was seen that the items were collected under five factors and all factors have five items that scale include totally 25 items. Factor loads ranging of factors are respectively; Contribution of Parents Factor from .852 and .770; School Administrators and Management Style from 
.884 and .819; School Characteristics appears from .866 and .795; Teacher-Related Factors from .853 and .779; the Impact of Students' Individual Characteristics from .829 and .731. It can be said that the model is reliable because the loads of all items are over 0.70 .

Cronbach's alpha coefficients for Contribution of Parents Factor was calculated as .872, Cronbach's alpha coefficient for School Administrators and Management Style Factor was calculated as .905, Cronbach's alpha coefficient for School Characteristics Factor was calculated as .882, Cronbach's alpha coefficient for Teacher-Related Factors Factor was calculated as .884, Cronbach's alpha coefficient for the Impact of Students' Individual Characteristics Factor was calculated as .854 .

Secondly, it is seen that the composite reliability values of the model vary between .895 and .930 . According to Bagozzi and Yi (1988), the composite reliability values of any measurement model for reliability should be .60 and above, and according to Fornell and Larcker (1981), CR (composite reliability) should be higher than 0.8 for good fit validity. Therefore, it is seen that all composite reliability values are quite high.

Rho_A is seen to vary between .930 and .895. Rho_A is the most important reliability measure for Partial Least Square (Dijkstra \& Henseler, 2015). Therefore, it is seen that reliability values are quite high.

When the AVE values of the model are examined, it is seen that these values vary between .632 and .725 values. Therefore, it can be said that the scale satisfies the condition that Fornell and Larcker (1981) stated that the AVE value should be above 0.5 for a good fit validity.

$R 2$ were examined for the amount of explanation of the model. $R 2=.46$ of Contribution of parents factor, $R 2=.68$ of school characteristics factor, $R 2=.60$ of Teacher-Related Factors factor, $R 2=.57$ of the Impact of Students' Individual Characteristics factor were calculated. Henseler et al (2009) proposed a basic rule for acceptable R2 with $0.75,0.50$, and 0.25 are described as substantial, moderate and weak respectively. Table 5 shows Fornell-Larcker values and the correlation values between the factors for the control of discriminant validity.

Table 5.

Fornell-Larcker Criterion of the Model 2

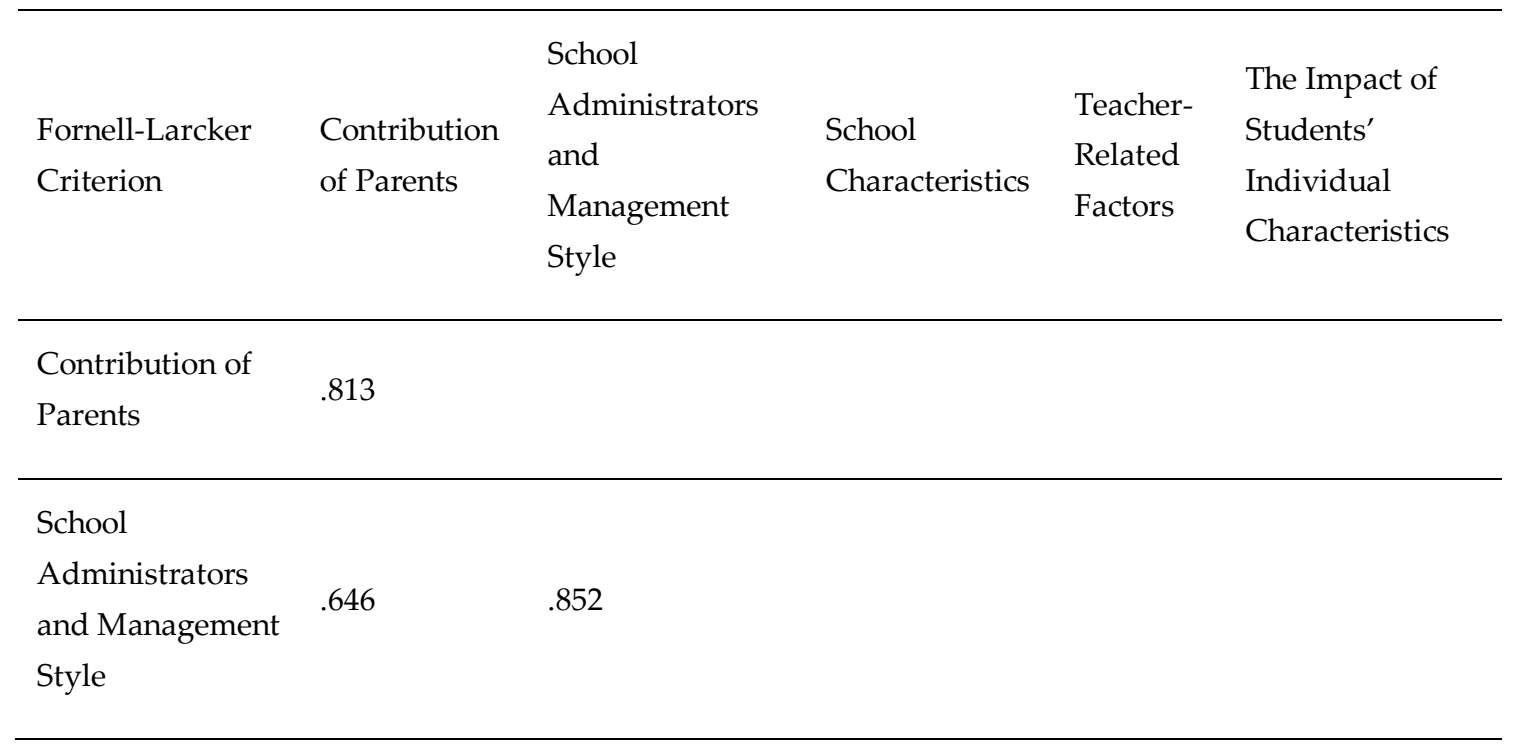




\begin{tabular}{|c|c|c|c|c|c|}
\hline $\begin{array}{l}\text { School } \\
\text { Characteristics }\end{array}$ & .624 & .766 & .825 & & \\
\hline $\begin{array}{l}\text { Teacher-Related } \\
\text { Factors }\end{array}$ & .627 & .775 & .778 & .827 & \\
\hline $\begin{array}{l}\text { The Impact of } \\
\text { Students' } \\
\text { Individual } \\
\text { Characteristics }\end{array}$ & .703 & .639 & .645 & .657 & .795 \\
\hline
\end{tabular}

Fornell-Larcker values (cross values) were found to vary between .852 and .795. Correlation values vary between .624 and .778. In all cases, since the crosstab values are higher than the values in the row and column, it can be said that the discriminant validity of the scale is supported.

Table 6.

Model Fit of the Model-2

\begin{tabular}{lll}
\hline Fit Summary & Saturated Model & Estimated Model \\
\hline SRMR & .056 & .058 \\
d_ULS & 1.021 & 1.098 \\
d_G & .663 & .670 \\
Chi-Square & 599.204 & 602.575 \\
NFI & .809 & .808 \\
\hline
\end{tabular}

* RMS Theta .145

Moreover, the standardized root mean square residual (SRMR) and other fit indices, namely the normed fit index (NFI) are used to test the model fit of the research model (Henseler et al., 2014). SRMR produces a value of 0.056 in saturated and 0.058 in estimated model.

The second fit index is normed fit index (NFI) that computes proposed model's the Chi-square value and compares this value with a meaningful benchmark (Bentler \& Bonett, 1980). The NFI results in values between 0 and 1 and the closer the NFI to 1, the better the fit (Ringle et al., 2015). NFI produces a value of .809 in saturated and 0.808 in estimated model.

The third fit value is full model fit that testing the statistical inference of the discrepancy between the covariance matrix and the empirical covariance matrix implied by the composite factor model (Ramayah 
et al. 2017). Henseler et al. (2016) stated that if d_ULS and d_G smaller than the $95 \%$ bootstrapped quantile, this means the model fits well. Furthermore, the chi-square value $(c 2=599.204 ; p<0.001)$ of the Model 2 appears to be significant.

RMS Theta value below 0.12 indicates a well-fit model (Henseler et al., 2014). For this model RMS Theta is 0.145 . Since the SRMR, NFI was better than the expected values, and the Chi-square value was significant, the model was considered to be in good fit. The results of the t-Statistics of the reconstructed model are given in the table below.

Table 7.

T-Statistics Results of the Model 2

\begin{tabular}{|c|c|c|c|c|c|c|c|}
\hline Paths & $\begin{array}{l}\text { Original } \\
\text { Sample } \\
(\mathrm{O})\end{array}$ & $\begin{array}{l}\text { Sample } \\
\text { Mean } \\
(\mathrm{M})\end{array}$ & $2.5 \%$ & $97.5 \%$ & $\begin{array}{l}\text { Standard } \\
\text { Deviation } \\
(\text { STDEV) }\end{array}$ & $\begin{array}{l}\text { T-Statistics } \\
\text { (O/STDEV) }\end{array}$ & $\begin{array}{l}p \\
\text { Values }\end{array}$ \\
\hline $\begin{array}{l}\text { Contribution of Parents } \\
>\text { School Characteristics }\end{array}$ & .130 & .129 & .027 & .255 & .058 & 2.231 & $.033^{*}$ \\
\hline $\begin{array}{l}\text { Contribution of Parents } \\
>\text { The Impact of } \\
\text { Students' Individual } \\
\text { Characteristics }\end{array}$ & .480 & .490 & .369 & .613 & .081 & 5.917 & $.000^{*}$ \\
\hline $\begin{array}{l}\text { School Administrators } \\
\text { and Management Style } \\
>\text { Contribution of } \\
\text { Parents }\end{array}$ & .401 & .441 & .184 & .538 & .106 & 3.797 & $.001^{*}$ \\
\hline $\begin{array}{l}\text { School Administrators } \\
\text { and Management Style } \\
\text { > School Characteristics }\end{array}$ & .355 & .376 & .196 & .509 & .081 & 4.363 & $.000^{*}$ \\
\hline $\begin{array}{l}\text { School Administrators } \\
\text { and Management Style } \\
>\text { Teacher-Related } \\
\text { Factors }\end{array}$ & .775 & .794 & .731 & .837 & .030 & 25.786 & $.000^{*}$ \\
\hline $\begin{array}{l}\text { Teacher-Related Factors } \\
>\text { Contribution of } \\
\text { Parents }\end{array}$ & .316 & .280 & .164 & .493 & .103 & 3.073 & $.004^{*}$ \\
\hline Teacher-Related Factors & .422 & .404 & .196 & .581 & .084 & 5.022 & $.000^{*}$ \\
\hline
\end{tabular}


$>$ School Characteristics

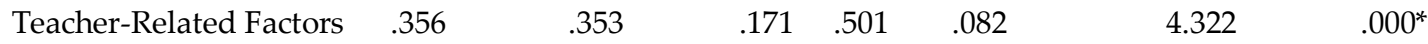

$>$ The Impact of

Students' Individual

Characteristics

${ }^{*} \mathrm{p}<.05$

Since the paths were significant in the model $(p>0.05)$, this model was accepted. Contribution of Parents was explained by $13 \%(R 2=0.128)$ of School Characteristics and $48 \%(R 2=0.481)$ the Impact of Students' Individual Characteristics. School Administrators and Management Style was explained by \%40 $(R 2=$ 0.402) of Contribution of Parents, \%31.5 $(R 2=0.315)$ of School Characteristics and \%77.5 $(R 2=0,775)$ of Teacher-Related Factors. Teacher-Related Factors was explained by \%31.5 $(R 2=0.315)$ of Contribution of Parents, \%42 $(R 2=0.423)$ of School Characteristics and \%35.5 $(R 2=0.355)$ of the Impact of Students' Individual Characteristics.

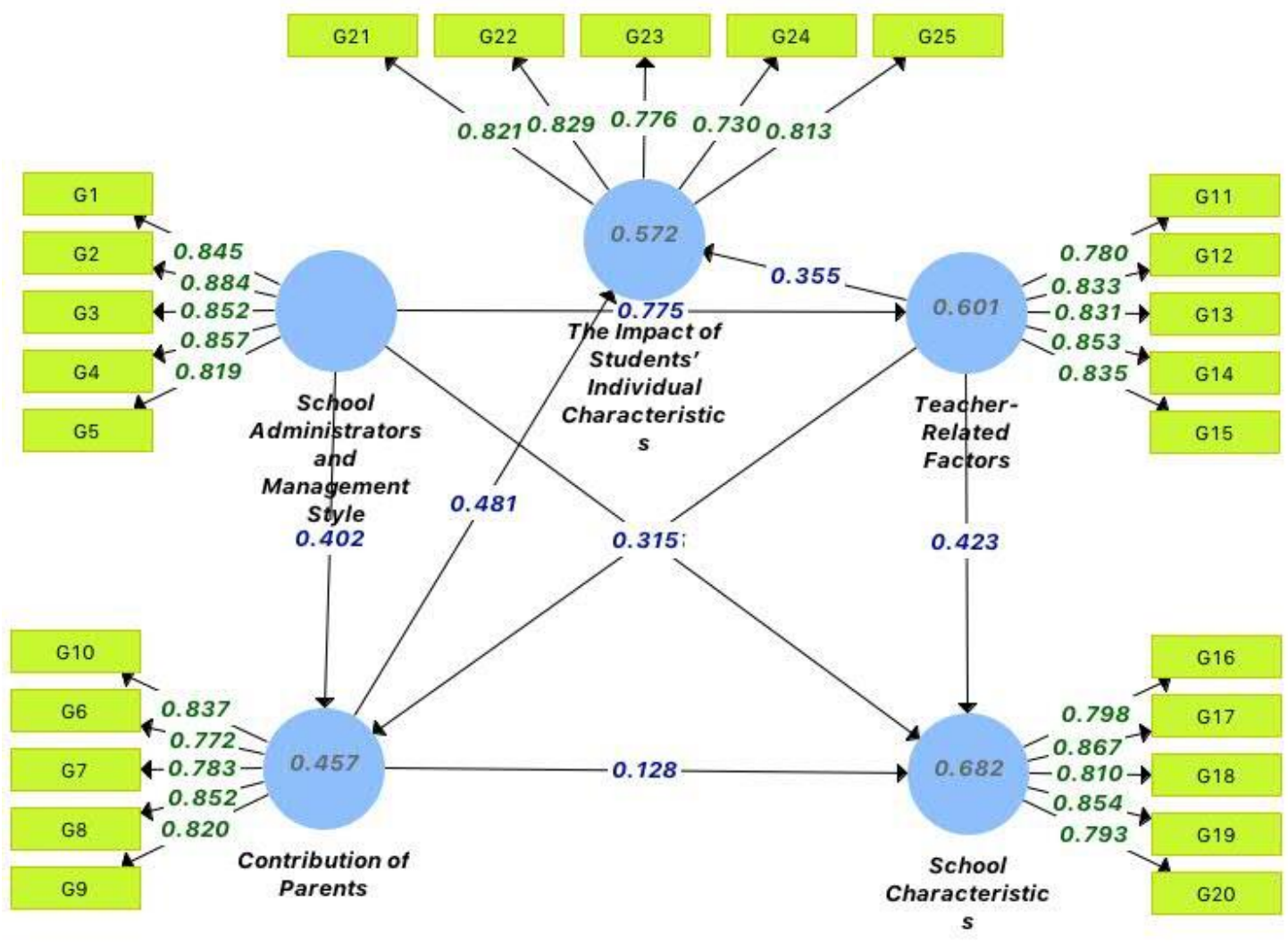

Figure 2. Path Model-2 of the Factors Affecting Future Expectations 


\section{DISCUSSION}

The Future Expectations Scale was prepared in order to determine the factors that affect the future expectations of students in the school environment. According to the findings obtained as a result of the study, it was found that the factors affecting young people's future expectations were associated with school administrators and management style, contribution of parents, teacher-related factors, school characteristics and the impact of students' individual characteristics. The findings obtained support the studies on this subject (İmamoğlu \& Güler-Edwards, 2007; McWhirter \& McWhirter, 2008; Tuncer, 2011a; Tuncer, 2011b). The compatibility of the structure obtained by exploratory factor analysis and the model was tested with confirmatory factor analysis. PLS-SEM was used to test the model. Since the sample size was small compared to the population of the Bursa, PLS-SEM was used in the analysis. Because PLS-SEM is a method used when the sample size is small. As a result of exploratory and confirmatory factor analysis, the scale consisting of twenty five items and five factors was found to be theoretically and statistically appropriate. The procedures performed during the development of the scale indicate that it is a valid and reliable scale. In addition, since there are few tools that measure the factors that affect future expectations in the literature review, it is thought that the scale will contribute to the field in literature and can meet this need. Preparing a scale development study for future expectations of different age groups and conducting researches in which the scale will be used in the literature will contribute significantly to the measuring power of this scale.

\section{REFERENCES}

Bagozzi, R. P., \& Yi, Y. (1988). On the evaluation of structural equation models. Journal of the Academy of Marketing Science, 16(1), 74-94. Retrieved from Doi: https://doi.org/10.1007/BF02723327

Bentler, P. M., \& Bonett, D. G. (1980). Significance tests and goodness of fit in the analysis of covariance structures. Psychological Bulletin, 88(3), 588. Doi: https://doi.org/10.1037/0033-2909.88.3.588

Dijkstra, T. K., \& Henseler, J. (2015). Consistent partial least squares path modeling. MIS quarterly= Management Information Systems Quarterly, 39(2), 297-316. Doi: 10.25300/MISQ/2015/39.2.02

Erçetin, Ş. Ş., \& Arifoğlu, A. (2016). Herkes için eğitim 2015 Hedefleri ve Türkiye. Bartın Üniversitesi Ĕ̆itim Fakültesi Dergisi, 5(2), 223-246. Doi: http://dx.doi.org/10.14686/buefad.v5i2.5000186142

Erçetin, Ş. Ş. (2001a). İlköğretim okulu yöneticilerinin 21. yüzyıl için kişisel vizyonları. Eğitim ve Bilim, 26(120), 37-43. Retrieved from http://egitimvebilim.ted.org.tr/index.php/EB/article/view/5250

Erçetin, Ş. Ş. (2001b). Yeni Yüzyıl için Türk üniversite rektörlerinin kişisel ve örgütsel vizyonları. Uludă̆ Üniversitesi Eğitim Fakültesi Dergisi, 14(1). Retrieved from https://dergipark.org.tr/tr/pub/uefad/issue/16676/173242

Erçetin, Ş. Ş. (2000). Lider sarmalında vizyon. Ankara: Nobel Yayın Dağıtım

Erçetin, Ş. Ş. (1997). İlkokul müdürlerinin vizyon geliştirmeye karşı tutumları (Araştırmaya Dayalı) Full text is published in "Leadership in 21. Century Symposium" Naval Academy. Istanbul 5-6 June 1997 ISBN 975-409-109-9 Deniz Harp Okulu Basımevi Tuzla, 126-132 
Fornell, C., \& Larcker, D.F. (1981). Evaluating structural equation models with unobservable variables and measurement error. Journal of Marketing Research 18(1), 39-50. Doi: 10.2307/3151312

Frank, L. K. (1939). Projective methods for the study of personality. The Journal of Psychology, 8(2), 389413. Doi: https://doi.org/10.1080/00223980.1939.9917671

Henseler, J., Ringle, C., \& Sinkovics, R. (2009). The use of partial least squares path modeling in international marketing. Advances in International Marketing (AIM), 20, 277-320. Doi: 10.1108/S1474-7979(2009)0000020014

Henseler, J., Dijkstra, T. K., Sarstedt, M., Ringle, C. M., Diamantopoulos, A., Straub, D. W., . . . Calantone, R. J. (2014). Common beliefs and reality about PLS: Comments on Rönkkö and Evermann (2013). Organizational Research Methods, 17(2), 182-209. Doi: https://doi.org/10.1177/1094428114526928

Henseler, Hubona, G., \& Ray, P. (2016). Using PLS path modeling in new technology research: updated guidelines. Industrial Management \& Data Systems, 116(1), 2-20. Doi: https://doi.org/10.1108/IMDS-09-2015-0382

Hu, L. T., \& Bentler, P. M. (1998). Fit Indices in Covariance Structure Modeling: Sensitivity to Underparameterized Model Misspecification. Psychological Methods, 3(4), 424-453. Doi: https://doi.org/10.1037/1082-989X.3.4.424

Israeli, N. (1930). Some aspects of the social psychology of futurism. Journal of Abnormal and Social Psychology, 25, 121-132. Doi: https://doi.org/10.1037/h0073258

İmamoğlu, E. O., \& Güler-Edwards, A. (2007). Geleceğe ilişkin yönelimlerde benlik tipine bağlı farklılıklar. Türk Psikoloji Dergisi, 22(60), 115-132. Retrieved from https://www.psikolog.org.tr/tr/yayinlar/dergiler/1031828/tpd1300443320070000m000145.pdf

Lewin, K. (1939). Field theory and experiment in social psychology: concepts and methods. The American Journal of Sociology, 44, 868-897. Doi: https://doi.org/10.1086/218177

McWhirter, E. H., \& McWhirter, B. T. (2008). Adolescent future expectations of work, education family and community. Youth \& Society, 40(2), 182-202. Doi: https://doi.org/10.1177/0044118X08314257

Ramayah, T., Yeap, J. A. L., Ahmad, N. H., Halim, H. A., \& Rahman, S. A. (2017). Testing a confirmatory model of Facebook usage in SmartPLS using consistent PLS. International Journal of Business and Innovation, 3(2), 01-14. Retrieved from https://www.theijbi.net/volume-3/issue-2-2017/testing-aconfirmatory-model-of-facebook-usage-in-smartpls-using-consistent-pls/

Ringle, C. M., Wende, S., \& Becker, J.-M. (2015). SmartPLS 3. Bönningstedt: SmartPLS.

Seigner, R. (2003). Adolescent future orientation: an integrated cultural and ecological perspective. Online Readings in Psychology and Culture, 6(1), 3-13. Doi: https://doi.org/10.9707/2307-0919.1056

Seijts, G. H. (1998). The importance of future time perspective in theories of work motivation. The Journal of Psychology, 132, 154-168. Doi: https://doi.org/10.1080/00223989809599156 
Şanlı, T., \& Saraçlı, S. (2015). Üniversite öğrencilerinin gelecek beklentileri üzerinde etkili olan faktörlerin analizi. Kafkas Üniversitesi İktisadi ve İdari Bilimler Fakültesi Dergisi, 6(11), 25-36. Retrieved from https://www.ceeol.com/search/article-detail?id=496807

Şimşek, H. (2012). Güneydoğu Anadolu Bölgesindeki lise öğrencilerinin gelecek beklentileri ve gelecek beklentilerini etkileyen faktörler. AKU, Kuramsal Eğitimbilim Dergisi, 5(1), 90-109. Retrieved from https://dergipark.org.tr/tr/pub/akukeg/issue/29344/314023

Tuncer, M. (2011a). Ergen gelecek beklentileri ölçeğinin türkçeye uyarlanması. Turkish Studies International Periodical for the Languages, Literature and History of Turkish or Turkic Volume, 6(3), 1265-1275. Doi: http://dx.doi.org/10.7827/TurkishStudies.2335

Tuncer, M. (2011b). Yükseköğretim gençliğinin gelecek beklentileri üzerine bir araştırma. Turkish Studies - International Periodical for the Languages, Literature and History of Turkish or Turkic, 6(2), 935-948. Doi: 10.7827/TurkishStudies.2265

Wong, K. K. (2013). Partial least squares structural equation modeling (PLS-SEM) techniques using SmartPLS. Marketing Bulletin, 24(1), 1-32. Retrieved from https://www.researchgate.net/publication/268449353 Partial_least_square_structural_equation _modeling_PLS-SEM techniques using_SmartPLS 


\section{APPENDIX}

The Future Expectations Scale

\section{Items}

\section{School Administrators and Management Style}

1 Organizing actions in the school to enrich the students' dreams about the future

2 Organizing extracurricular activities at the school to help students recognize their interests and abilities

3 Organizing social responsibility projects to improve students' sensitivity to social problems

4 Providing sharing environments where students can talk to their friends about what they want to do in the future

5 Giving information about how students will be able to cope with the obstacles they will face while realizing their dreams in the future.

\section{Contribution of Parents}

6 Supporting student's dreams about the future by parents

7 Supporting students to set goals that he / she can achieve rather than his / her wishes when planning the future by parents

8 Enlightening the students about the choice of the profession to be happy by parents

9 Ability to chat with parents about what kind of life the student wants to have in the future

10 Encouraging the students to cope with the difficulties faced by the parents in fulfilling their expectations

\section{Teacher-Related Factors}

11 Chatting with students about the profession they want to be in the future of teachers

12 Helping students find out what their interests are by teachers

13 Talking about how they can get one step closer to their dreams if they become diligent with students by teachers

14 Talking students about what kind of work life they want in the future by teachers

15 Enlightening the students about the stages they will go through while realizing their dreams by teachers

\section{School Characteristics}

16 Making projects in the school environment to enable students to think about where they see themselves after five years

17 Conducting studies that students will be able to recognize the strengths and weaknesses in the 
school environment,

18 Creating an environment that teaches respect for differences in school

19 Providing opportunities for students to chat and discuss their future expectations in school environment

20 Supporting students to develop their skills in dealing with challenges in the school environment

\section{The Impact of Students' Individual Characteristics}

21 Having dreams about what kind of life the student wants to have in the future

22 Knowing how to develop students' talents to realize dreams

23 Knowing that no matter what work the student does in the future, s/he should be an honest person

24 Sharing with friends about the profession they want to do in the future

25 Having courage to overcome the obstacles that come before students' dreams

\section{Gelecek Beklentileri Ölçeği}

\section{Maddeler}

\section{Okul Yöneticileri ve Yönetim Stilleri}

1 Öğrencilerin gelecekle ilgili hayallerini zenginleştirmek için okulda eylemler düzenlemek

2 Öğrencilerin ilgi ve yeteneklerini anlamalarına yardımcı olmak için okulda ders dışı etkinlikler düzenlemek

3 Öğrencilerin sosyal sorunlara duyarlılıklarını artırmak için sosyal sorumluluk projeleri düzenlemek

4 Öğrencilerin gelecekte ne yapmak istedikleri hakkında arkadaşlarıyla konuşabilecekleri paylaşım ortamları sağlamak

$5 \quad$ Öğrencilerin gelecekte hayallerini gerçekleştirirken karşılaşacakları engellerle nasıl başa çıkacakları hakkında bilgi vermek.

\section{Ebeveynlerin Katkısı}

6 Ebeveynler tarafından öğrencinin gelecekle ilgili hayallerini desteklemek

$7 \quad$ Öğrencileri geleceği veliler tarafından planlarken istekleri yerine ulaşabilecekleri hedefler belirlemede öğrencilere destek olmak

8 Öğrencilerin mesleğin seçimi konusunda veliler tarafından mutlu olmaları konusunda aydinlanması

9 Öğrencinin gelecekte nasıl bir yaşam yaşamak istediği konusunda ebeveynlerle sohbet edebilme

10 Öğrencileri, ailelerinin beklentilerini karşılamada karşılaştıkları zorluklarla başa çıkmaya teşvik 
etmek

\section{Öğretmenle İlgili Faktörler}

11 Öğretmenlerin geleceğinde olmak istedikleri meslek hakkında öğrencilerle sohbet etmek

12 Öğrencilerin öğretmenlerin ilgi alanlarını bulmalarına yardımcı olmak

13 Öğretmenler tarafından öğrencilerle çalışkan hale gelirlerse hayallerine nasıl bir adım daha yaklaşabilecekleri hakkında konuşmak

14 Öğrencilerle gelecekte öğretmenler tarafından ne tür bir çalışma hayatı istedikleri hakkında konuşmak

15 Öğretmenler tarafından hayallerini gerçekleştirirken öğrencilere geçecekleri aşamalar hakkında aydınlanma

\section{Okul Özellikleri}

16 Öğrencilerin beş yıl sonra nerede gördüklerini düşünmelerini sağlamak için okul ortamında projeler yapmak

17 Öğrencilerin okul ortamındaki güçlü ve zayıf yanlarını tanıyabilecekleri çalışmalar yapmak,

18 Okuldaki farklılıklara saygıyı öğreten bir ortam yaratmak

19 Öğrencilerin okul ortamındaki gelecekteki beklentilerini sohbet etme ve tartışma fırsatı sağlama

20 Öğrencilerin okul ortamındaki zorluklarla başa çıkma becerilerini geliştirmelerine yardımcı olmak

\section{Öğrencilerin Bireysel Özelliklerinin Etkisi}

21 Öğrencinin gelecekte nasıl bir yaşam yaşamak istediğini hayal etmek

22 Hayallerini gerçekleştirmek için öğrencilerin yeteneklerini nasıl geliştireceklerini bilmek

23 Öğrencinin gelecekte ne işi olursa olsun, dürüst bir insan olması gerektiğini bilerek

24 Gelecekte yapmak istedikleri mesleği arkadaşlarla paylaşmak

25 Öğrencilerin rüyalarının önündeki engellerin üstesinden gelmek için cesaret sahibi olmak 